\title{
市販食品加らの志賀毒素産生大腸菌の検出
}

\author{
小田隆弘・椿本 亮・財津修一・池田嘉子 \\ 樋脇 弘・金堂正也 \\ （福岡市保健環境研究所） \\ （受付 平成 9 年 9 月 17 日） \\ （受理 平成 9 年 11 月 5 日）
}

\section{Detection of Shiga Toxin Producing Escherichia coli from Commercial Foods}

\author{
Takahiro OdA, Makoto Tsubakimoto, Shuichi Zaitsu, \\ Yoshiko Ikeda, Hiroshi Hiwaki and Masaya Kanadou \\ (Fukuoka City Institute for Hygiene and Environmental \\ Science, 2-1-34 Jigyohama, Chuo-ku, Fukuoka 810)
}

Key words: Shiga toxin producing Escherichia coli, Commercial foods, Colony sweeps method

はじめに

腸管出血性大腸菌 O157（以下 O157 之略）集団感染 事例が 1996 年に我が国の各地で発生し, 社会的に大き な問題となった。 これらの集団事例のうち, 感染源が特 定された事例は数例しかなく, 大多数の事例では原因食 品などの感染源は不明である。福岡市でも1996 年 6 月 中旬に, 保育園で患者数 48 名の集団事例が発生し, 原 因として保育園給食が疑われたものの，感染源となった 食品などを特定することはできなかった，また，その後 に発生した散発事例約 60 例 (1996 年 7 月から 1997 年 3 月までに発生した件数）においても，すべて感染源の 特定はできなかった。

腸管出血性大腸菌感染症（食中毒を含む）の原因菌は O157 によるあのが最む多いが，O26，O111，0128な どほかの血清型による事例も報告 ${ }^{14)}$ されている. 腸管出 血性大腸菌の主要な病原因子が, 志賀毒素 (本論文では, 従来, ベロ毒素と呼ばれてきた毒素を志賀毒素〔Shiga

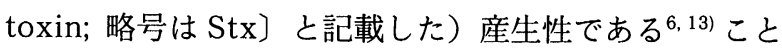
は分かっている. 一方, 牛などの家畜からは多種類の血 清型の Stx 産生菌が分離されることも報告10)されてい る. Stx を産生する大腸菌が，すべてヒトに腸管出血性 大腸炎を引き起こす病原菌であるかどうかは今のところ 明確ではない，また，ヒトの腸管出血性大腸菌感染症の 原因菌は, O157 によるあのが圧倒的に多い理由も判明 していない.したがって, 今のところは Stx 産生大腸菌 (Shiga toxin producing Escherichia coli: 以下 STEC

焉810 福岡市中央区地行浜 2-1-34
と略）を腸管出血性大腸菌と見做して対策を立てるべき と考えられるが，O157を含めた STEC についての食品 污染調査の報告は少なく, 市販食品における分布状態は 不明な点が多い.

著者らは, 福岡市内で市販されていた食品 677 件につ いて, 1996 年 7 月から 1997 年 3 月までの期間に, O157 はじめとする STEC の污染調查を行ったので, その結果を報告する。

\section{材料および方法}

\section{1. 調查対象とした食品および細菌}

1996 年 7 月から 1997 年 3 月の期間に福岡市内で販 売されていた食品 677 件を対象に STEC の検查を行っ た.

\section{2. 検查方法}

STEC の検查法は, KARMALI ら $ら^{7)}$ のコロニー掻き取 り」(colony sweep) 法を参考にして, 図 1 に示した方法 により行った.

検査対象とした食品は, $20 〜 25 \mathrm{~g}$ に約 9 倍量のノボ ビオシン加 $\mathrm{mEC}$ ブイヨンを加えてホモゲナイズ後, 37 または $42^{\circ} \mathrm{C} て ゙ 1$ 晚（14 18 時間）培養した. 分離平板 はソルビトールマッコンキー寒天培地 (OXOID; 以下 $\mathrm{SMAC}$ と略) および覀テルル酸カリウムを $2.5 \mathrm{mg} / \mathrm{L} の$ 濃度で加えた SMAC（TSMAC と略す）を併用し, 培養 液を白金耳で常法ど扔り塗沫した。 1 晚 $37^{\circ} \mathrm{C}$ で培養し た SMAC 平板および TSMAC 平板のコロニー密集部を $3 \sim 5$ 白金耳量集め（コロニーを掻き取り），ポリミキシ 


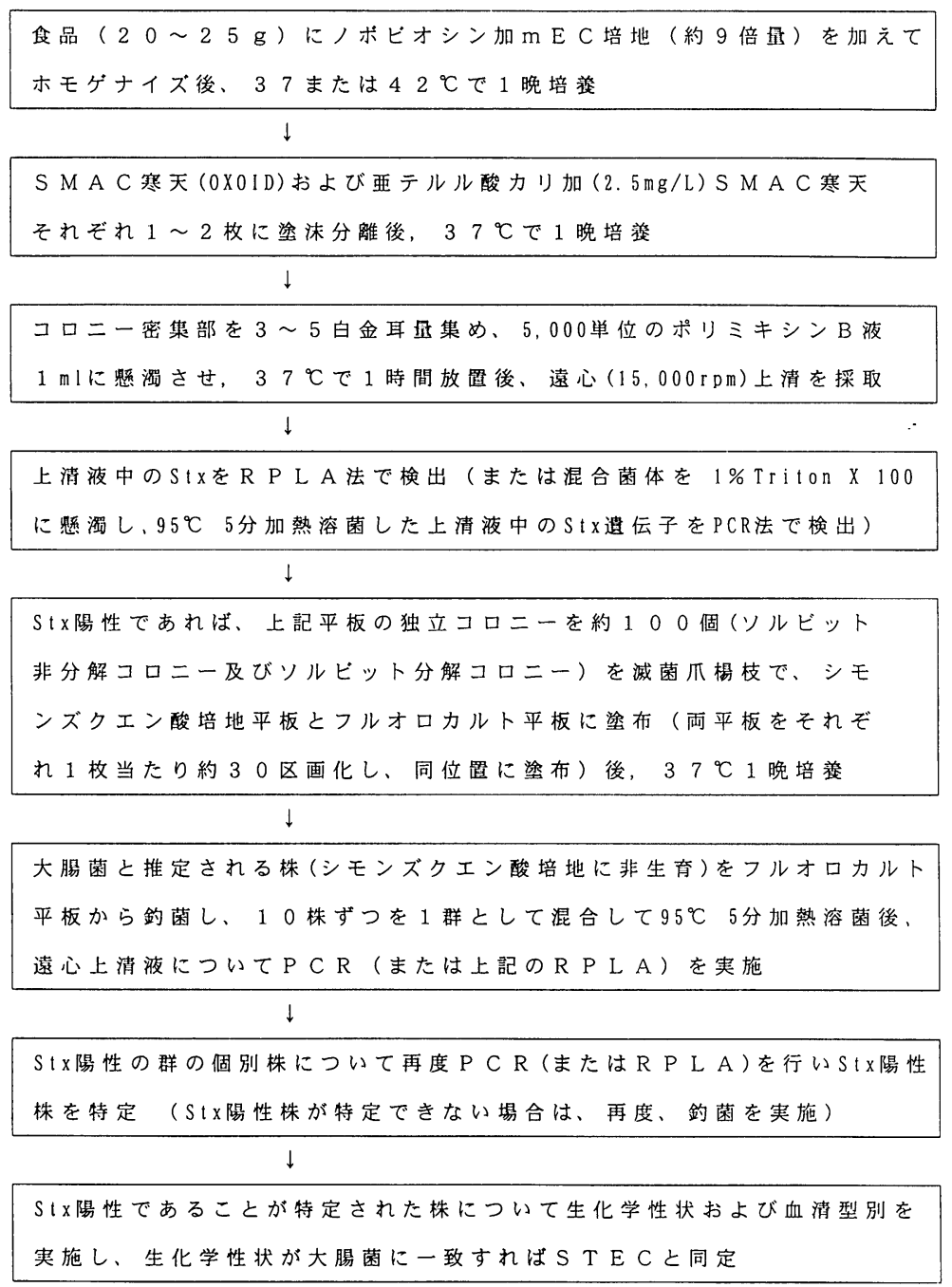

図 1 食品加の STEC 検出法

ン B 溶液 $(5,000$ 単位 $/ \mathrm{mL}) 1 \mathrm{~mL}$ に懸濁し， $37^{\circ} \mathrm{C}$ で 1 時間放置後, 遠心 $(15,000 \mathrm{rpm} / \mathrm{min})$ 上清を採取した。 上清中の Stx の有無を市販キット（べロ毒素検出用 RPLA キット; デンカ生研)を用いた RPLA 法5) で調べ た. RPLA 法の代わりに, Stx 遗伝子を PCR 法で検出 する方法 ${ }^{8)}$ 用いた. PCR 法を用いる時の「コロニー掻 き取り」法は，SMAC 平板のコロニ一密集部を $1 \sim 2$ 白 金耳量集め, $1 \%$ Triton X100 $1 \mathrm{~mL}$ に懸濁し, $95^{\circ} \mathrm{C} 5$ 分で加熱溶菌後, 遠心 $(15,000 \mathrm{rpm} / \mathrm{min})$ 上清を採取 し，上清中の Stx 遺伝子の有無を市販の primer（「VT 遗伝子検出用プライマーセット」TaKaRa）を用いた PCR 法により調べた.この時の PCR 法の条件は primer 添付書の条件に従った。

コロニ一混合物抽出液中に Stx またはStx 遺伝子が 検出されなかった場合は，STEC 陰性とした，同抽出液 中にStx またはStx 遺伝子が検出された場合は,「コロ ニ一掻き取り」に用いた SMAC平板および TSMAC 平 板上の独立.コロニー約 100 個をそれぞれ隇菌爪楊枝で 釣菌し,シャーレ裹に格子状に区画線を描いたシモンズ クエン酸培地 (栄研) 平板およびフルオロカルト（メル

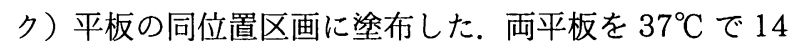
時間以上培養し, シモンズクエン酸培地に生育せず, フ ルオロカルト平板に生育した菌を推定大腸菌として以下 の検査を実施した. フルオロカルト平板上の推定大腸菌 コロニーを 10 株ずつ釣菌混合したものを 1 群とし，再 び上記の PCR（または RPLA）法を用いて Stx 産生菌 を検索した。Stx 産生菌の存在か認められた混合菌群を 対象に, その群を構成する個々のコロニーについて再度 PCR（または RPLA）法を行い, Stx 産生菌を特定した. 特定された株について, 通常の生化学性状検查を行い, 大腸菌であることが確認された株を STEC とした.

\section{3. 血清型別検査}

STECであることが確認された株は, 市販血清（デン 力生研) による血清型別検查（O型別および $\mathrm{H}$ 型別）を 実施した．市販血清により型別できなかった株は国立感 染症研究所細菌部外来性細菌室長 田村和満先生に型別 を依頼した。 


\section{結果}

\section{1. 市販食肉類からの STEC 検出}

平成 8 年 7 月から平成 9 年 3 月までの 9 力月間に, 福岡市内で販売されていた食肉類（食肉および内臓類） 157 件について STEC の污染状況を調べた結果を表 1 に示した。

STEC は， 157 件中 11 件 (6.9\%) から検出されたが, うち, 0157 が検出されたすのは 6 件 (3.8\%) であった. 検体数が 1〜2 件と少なかったものを除いて STEC の陽 性率を比較すると，最す高かったすのは，牛の腸で $16.1 \%$ の陽性率であった。牛肉では $2.4 \%$ ，牛レバーで は $3.4 \%$ の STEC 陽性率であった．牛肉または牛内臓類 以外では, 豚の内臓 (腸) および羊肉（ラム）からそれ ぞれ 1 件ずっ STEC が検出された. STEC が検出され た時期を；夏期（7～9 月）と秋冬期（10３月）に分け て比較してみると，夏期では 7.5\%（120 件中 9 件)，秋 冬期では 5.4\%（37 件中 2 件）と大きな差は認められな かった．１57 の陽性率においても，夏期で 3.3\%（120 件中 4 件), 秋冬期で 5.4\% (37 件中 2 件) と明らかな差 は認められなかった。

分離されたSTEC の血清型は, 牛肉 1 件から 044 : $\mathrm{H} 8$ (Stx1+Stx2) が，牛レバー 1 件から $0157: \mathrm{H} 7$ (Stx $1+\mathrm{Stx} 2)$ が，牛せんまい 1 件から $0157: \mathrm{H} 7$ (Stx2) お よび O161: H- (Stx 1) が，牛さがり肉 1 件から 0113 : $\mathrm{H} 4$ (Stx1+Stx2) が, 牛の腸の 4 件から $0157: \mathrm{H} 7$ (Stx $1+\mathrm{Stx} 2), 1$ 件から $0161: \mathrm{H} 9$ (Stx2) が, 豚の腸 1 件か ら $0161: \mathrm{H} 9$ (Stx2) が, 羊肉 (ラム; 密封包装品) 1 件か ら 091: H- (Stx1+Stx2) がそれぞれ検出された。分離
された STEC の血清型数と株数は, 計 6 種 12 株であ り, O157: H7 が半数の 6 株を占めた. O157:H7 以外 の血清型では，O44:H8, O113:H4, O161:H9（または $\mathrm{H}-$ ) など，今までにヒトからも家畜からもほとんど分離 されたことがない1,2,9,10) STEC が検出された.

\section{2. その他の食品からの STEC 検出}

食肉類以外の市販食品 520 件についても, 食肉類と同 様な方法で STEC の検出を試みた結果を表 2 に示した.

刺身などの鮮魚類 54 件をはじめ, 野菜・果物（カッ 卜品） 43 件ならびに多種類の加工食品すべてから STEC は 1 件む検出されなかった。

\section{表 2 食肉類以外の食品からの STEC 検出}

\begin{tabular}{|c|c|c|}
\hline 食品名 & 供試検体数 & STEC 陽性数 \\
\hline 食肉製品（ハム等） & 20 & 0 \\
\hline 鮮魚介類（刺身等） & 54 & 0 \\
\hline 生カキ & 18 & 0 \\
\hline 魚介類加工品（辛子めんたい等） & 59 & 0 \\
\hline 野菜・果物（カット品） & 43 & 0 \\
\hline 原乳（生乳） & 4 & 0 \\
\hline 牛乳・乳製品 & 37 & 0 \\
\hline 鶏卵・液卵 & 29 & 0 \\
\hline 卵製品（卵焼き等） & 22 & 0 \\
\hline 生菓子（和洋） & 23 & 0 \\
\hline 弁当・調理パン & 63 & 0 \\
\hline 加熱・未加熱笏菜 & 94 & 0 \\
\hline 生麺・ゆで麺 & 32 & 0 \\
\hline 豆腐 & 4 & 0 \\
\hline 冷凍食品（凍結前未加熱/加熱） & 6 & 0 \\
\hline 自販機の清涼飲料水 & 12 & 0 \\
\hline 計 & 520 & 0 \\
\hline
\end{tabular}

表 1 市販食肉類からの STEC の検出

\begin{tabular}{|c|c|c|c|c|c|}
\hline & & \multicolumn{3}{|c|}{ STEC 陽性率（陽性数/検查数） } & \multirow{2}{*}{ 検出された STEC の血清型（毒素型） } \\
\hline & & $7 \sim 9$ 月 & $10 \sim 3$ 月 & 合計 (\%) & \\
\hline \multirow[t]{7}{*}{ 牛肉類 } & 牛肉 & $1 / 29$ & $0 / 13$ & $1 / 42(2.4)$ & $\mathrm{O} 44: \mathrm{H} 8(\mathrm{Stx} 1+\mathrm{Stx} 2)$ \\
\hline & レバー & $1 / 27$ & $0 / 2$ & $1 / 29(3.4)$ & $\mathrm{O} 157: \mathrm{H} 7(\mathrm{Stx} 1+\mathrm{Stx} 2)$ \\
\hline & せんまい & $1 / 7$ & $0 / 2$ & $1 / 9(11.1)$ & $\mathrm{O} 157: \mathrm{H} 7(\mathrm{Stx} 2)+\mathrm{O} 161: \mathrm{H}-(\mathrm{Stx} 1)$ \\
\hline & たん & $0 / 2$ & & $0 / 2$ & \\
\hline & さがり & $1 / 1$ & & $1 / 1(100)$ & $\mathrm{O} 113: \mathrm{H} 4(\mathrm{Stx} 1+\mathrm{Stx} 2)$ \\
\hline & 腸 & $3 / 23$ & $2 / 8$ & $5 / 31(16.1)$ & $\mathrm{O} 157: \mathrm{H} 7(\mathrm{Stx} 1+\mathrm{Stx} 2) ; 4$ 件 \\
\hline & & & & & $\mathrm{O} 161: \mathrm{H} 9$ (Stx2); 1 件 \\
\hline \multirow[t]{2}{*}{ 豚肉類 } & 豚肉 & $0 / 2$ & $0 / 8$ & $0 / 10$ & \\
\hline & 内臓(腸) & $1 / 2$ & & $1 / 2(50)$ & O161 : H9 (Stx2) \\
\hline \multirow[t]{3}{*}{ 鶏肉類 } & 彩鳥肉 & $0 / 11$ & $0 / 3$ & $0 / 14$ & \\
\hline & レバー & $0 / 11$ & & $0 / 11$ & \\
\hline & 砂ずり等 & $0 / 3$ & $0 / 1$ & $0 / 4$ & \\
\hline \multirow[t]{2}{*}{ 他肉類 } & 馬肉 & $0 / 1$ & & $0 / 1$ & \\
\hline & 羊肉(ラム) & $1 / 1$ & & $1 / 1(100)$ & $\mathrm{O} 91: \mathrm{H}-(\mathrm{Stx} 1+\mathrm{Stx} 2)$ \\
\hline \multirow{2}{*}{\multicolumn{2}{|c|}{$\begin{array}{l}\text { 計 } \\
\text { STEE 陽性率 }\end{array}$}} & $9 / 120$ & $2 / 37$ & $11 / 157$ & \\
\hline & & $(7.5)$ & $(5.4)$ & $(6.9)$ & \\
\hline \multicolumn{2}{|c|}{ うち 0157 陽性率 } & $4 / 120$ & $\begin{array}{l}2 / 37 \\
(5,4)\end{array}$ & $6 / 257$ & \\
\hline
\end{tabular}




\section{考 察}

ヒトの下痢症から分離される STEC の血清型は, 圧倒 的に $0157: \mathrm{H} 7$ (または H-) が多いが，その他の血清型 の STEC による事例も多数報告されており, 諸外国での 分離例を調べた報告 ${ }^{2}$ 15) によれば，O 抗原の種類だけで も30 種を超えている. 我が国においても，O157: H7 (または H-) 以外に O26:H11（または $\mathrm{H}^{-}$), $0145: \mathrm{H}^{-}$, O111: H-, O128: H2 などによるヒト感染事例が報 告 ${ }^{12,13)}$ されている.

SMACまたはSIB平板上のソルビット非分解コロ ニーを釣菌する方法や，O157 抗体を利用して ELISA 法により検出する方法または磁気ビーズにより集菌する 方法 ${ }^{4}{ }^{11)}$ は, O157 の検查を目的に開発されたものであ り, O157 だけではなく, 他の血清型の STEC む対象に 検査する場合には，これらの方法でははなはだ困難であ る. 0157 に限って検査する場合においても，共存する 類似菌（STEC 以外の大腸菌）の量や類似菌と STEC の 比率, また, 分離平板から釣菌するコロニー数などに よって検出率は大きく左右される.

著者らが今回行った「コロニー掻き取り法」では, 多 数（少なくとも 1,000 以上）のコロニーを対象に Stx 産 生菌を検索できるため, 効率的に 0157 以外の血清型む 含めた STEC の検出が可能であった. 表には示していな いが, この方法では, 分離平板上の STEC コロニーが類 似の大腸菌様コロニーの $1 \%$ 以下程度でも検出が可能 であり, 今回の市販食品の調查成績でも, STEC が検出 された 11 例のうちすべてで, SMACおよびTSMAC 平板から釣菌した 100コロニー中, STEC は 1〜5 個程 度の検出率であった. なお，STEC 検出における「コロ

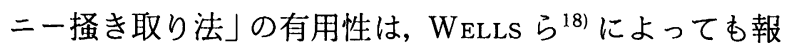
告されている.

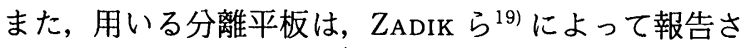
れた Cefixime-Tellulite SMAC (CT-SMAC) が O157 の 選択性に優れていることは確認されている ${ }^{12)}$. 一方, 著 者らは, Cefixime を加えないTSMAC が CT-SMAC に 劣らない選択性を有していることを見いだしているが, すべての STEC がTSMAC に生育するのかどうかはま だ分かっていないため, 現在のところは, TSMAC と SMAC を併用する方がよいと思われる.

我が国における市販食品の STEC 污染率調查は, 田中

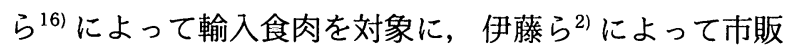
食肉を対象に実施されており，それぞれSTEC 陽性率 は, $1.9 \% ， 2.6 \%$ という值が報告されている. 今回の私 どもの調査でも, 牛肉に抢いては $2.4 \%$ であり, ほぼ同 じであった。牛の内臓類では陽性率が $11.1 \%$ と高く, 特に腸では $16.1 \%$ と高率な值であった.これらは, 過 去に我が国で調べられた家畜牛（腸管, 糞便または体表 など）からの高い STEC 検出率 ${ }^{119)}$ を反映しているもの と考えられる. STECがすべてヒトに腸管出血性大腸炎
を引き起こす病原菌かどうかは今のところ明確ではな い. したがって, 今回得られた STEC 陽性率が，そのま まヒトの腸管出血性大腸炎発生の危険性を示すむのとは いえないが，O157 の陽性率の高さから見ても，牛の内 臓類が㛜重な注意を要する食品であると考えられた。内 臓類のうち，レバーの STEC 陽性率は $3.4 \%$ （検出され た株はいずれも O157）であったが，レバーは好んで生 食される食品であることから, 特に厳重な注意が必要で あろう. 現に, 神奈川県では生レバーの喫食が原因であ ることが証明された 0157 感染事例が起こっており, 福 岡市においても, 生レバーの喫食が原因と推定される STEC 感染散発事例が 10 数例発生している。このよう なことから，生食用レバーについては衛生基準および加 工基準等を早急に制定する必要があると考える.

食肉および内臓類以外の食品 520 件からは, 今回, STEC は検出されなかった. しかし, 我が国の最近の STEC 集団感染事例では野菜類またはその加工品からも STEC が分離されており, 食肉および内臓類以外の食品 の STEC 污染率については今後, むっと多数の検体につ いての調査が必要と思われる.

今回の調查から，ヒトの STEC 感染 (食中毒) を防止 する上で, 現在最む緊急な課題は, 食肉および内蔵類か らの感染防止と, それらから他の食品への二次污染の防 止であることが明らかとなった。

\section{謝辞}

分離された O 157 以外の STEC の血清型別を行って 頂いた厚生省感染症研究所細菌部外来性細菌室長 田村 和満先生に感謝いたします。

\section{文献}

1）早矢仕裕子, 宗村佳子, 柴田和彦, 吉原雅子, 与那原美恵 子, 草野友子, 丸山啓二, 佐竹浩之, 宮尾陽子, 鈴木輝 康, 堀内亮三, 白石義明, 尾崎正美, 木下正彦, 中尾厚 義, 甲斐明美, 金子誠二, 尾畑浩魅, 伊藤 武: 肥育牛に おりる Vero 毒素産生性大腸菌の保菌実態調查. 食品衛 生研究, 43(5), 73-79 (1993).

2) 伊藤 武: ベロ毒素産生性大腸菌と食品衛生. モダンメ ディア, 39, 307-322 (1993).

3）伊藤 武, 甲斐明美：腸管出血性大腸菌食中毒の発生状 況. 医学のあゆみ, 178, 909-914 (1996).

4) 伊藤 武, 甲斐明美, 尾畑浩魅, 貫名正文, 黒木 学, 仲 西寿男：食品からの腸管出血性大腸菌 O157 検出法. 日 食微誌, 13, 205-219 (1997).

5）甲斐明美, 山田澄夫, 伊藤 武, 工藤泰雄, 大橋 誠：大 腸菌が産生するVerocy totoxin の逆受身ラテックス凝 集反応法による検出法の検討とその応用. 日細菌誌，43, 307-310 (1988).

6) Karmali, M. A., Petric, M., Lim, C., Fleming, P.C., Arbus, G. S. and Lior, H.: The association between idiopathic hemolytic uremic syndrome and infection by verotoxin-producing Escherichia coli. J. Infect. Dis., 151, 775-782 (1985). 
7) Karmali, M. A., Petric, M., Lim, C., Cheung, R. and Arbus, G. S.: Sensitive method for detection low numbers of verotoxin-producing Escherichia coli in mixed cultures by use of colony sweeps and polymyxin extraction of verotoxin. J. Clin. Microbiol., 22, 614619 (1985).

8）小林一寛：腸管出血性大腸菌の同定法 2, PCR 法. 臨床 検査, 36, 1334-1338 (1992).

9）中澤宗生, 甲斐明美：日本のウシ由来べロ毒素産生性大 腸菌の性状. 感染症誌, 68, 1437-1439 (1994).

10）仁科徳啓, 神田 隆：動物及び食肉における腸管出血性 大腸菌分布. 日食微誌，13, 199-204 (1997).

11) Okrend, A. J. G., Rose, B. and Lattuada, C. P.: Isolation of Escherichia coli 0157 specific antibody coated magnetic beads. J. Food Prot., 55, 214-217 (1992).

12）尾上洋一, 古川一郎, 寺西 大, 長谷川幸江, 森 實, 小沼博隆：挽き肉からの Escherichia coli $\mathrm{O} 157$ : H7 の 検出法の検討. 食衛誌, 38, 185-189 (1997).

13）坂崎利一：志賀毒産生性（腸管出血性）大腸菌一細菌学 的性状, 病原性および発症機序一. 日食微誌, 13,187193 (1997).
14）竹田美文：大腸菌による出血性大腸炎. 微生物, 3,137142 (1987).

15）竹田美文：病原大腸菌に関する最近の動向について. 食 品衛生研究, 41(7), 7-16 (1991).

16) 田中 博, 西内 力, 近藤玲子, 木村真理, 目見田 清, 菊池正健, 塚本定三, 奥 裕一, 山崎伸二, 竹田美文: Vero 毒素産生性大腸菌 (VTEC) の輸入食肉からの分離. 感染症誌, 65, 175-180 (1991).

17）渡邊治雄：腸管出血性大腸菌 $\mathrm{O} 157: \mathrm{H} 7$ による食中毒と その予防. 食品衛生研究, 46(8), 7-16 (1996).

18) Wells, J. G., Shipman, L. D., Greene, K. D., Sowers, E. G., Green, J. H., Cameron, D. N., Downes, F. P., Martin, M. L., Griffin, P. M., Ostroff, S. M., Potter, M. E., Tauxe, R.V. and Wachsmuth, I. K.: Isolation of Escherichia coli serotype O157:H7 and other Shiga-like-toxinproducing $E$. coli from dairy cattle. J. Clin. Microbiol., 29, 985-989 (1991).

19) Zadic, P. M., Chapman, P. A. and Siddons, C. A.: Use of tellulite for the selection of verotoxigenic Escherichia coli O157. J. Med. Microbiol., 39, 155-158 (1993). 